\title{
Loan Appraisal Protocol for Effective Microfinance Portfolio in Tanzania
}

\author{
Danstun B. Ngonyani ${ }^{1}$
}

RESEARCH

ARTICLE

\section{ARTICLE INFO}

Submitted : 06.05.2020

Revised : 10.08.2020

Accepted : 28.08.2020

Available : 29.12 .2020

iThenticate similarity score: $10 \%$

JEL classification:

G21, G23, G32

Keywords:

Portfolio at Risk, Loan Appraisal Protocol, Non-Member-Based Microfinance Institutions

\begin{abstract}
A B S T R A C T
This paper attempts to determine the effects of loan application appraisal on microfinance institutions' portfolio performance in Tanzania. The study utilizes a random sampling method and ordinary least square regression model on 219 microfinance entities collected from Dar es Salaam, Morogoro, and Dodoma regions. The finding indicates borrower business income, capital of borrower, membership duration of the borrower, and social collateral of borrowers negatively and significantly influences portfolio at risk of microfinance entities. These results, therefore, reveal that (i) microfinance institutions can reduce microfinance portfolio at risk to consider sound cash flow of the main business of microfinance client to enhance repayments; (ii) microfinance institutions must provide credit facilities to borrowers with relatively high capital in their business; (iii) microfinance institutions should extend credits to borrowers who are frequently willing to access credit facilities to enhance regular repayments; (iv) microfinance institutions should encourage borrowers to use group lending when accessing credits for effective repayments and diminish the risk of the microfinance loan portfolio.
\end{abstract}

Cite this article as: Ngonyani, D. B. (2020). "Loan Appraisal Protocol for Effective Microfinance Portfolio in Tanzania", International Journal of Public Finance, 5(2), 193-210.

\section{Introduction}

Microfinance entities are essential sources of finance to low income and disadvantaged individuals in facilitating financial inclusion. The influence of their activities has resulted in many such institutions in developing countries, including Tanzania. Among the services extended by microfinance institutions includes micro,

\footnotetext{
1 Lecturer, St. John's University, Faculty of Commerce and Business Studies, Tanzania, ORCID: 00000003-2903-1962, danstunngonyani@gmail.com
} 
small and medium credit services and non - financial skills to low-income individuals for enhancing their entrepreneurship activities (Mapesa, 2012; Arthur et al., 2016).

Studies by Ishengoma (2010) and Kessy and Urio (2006) reveals most lowincome individuals do not access the services offered by financial institutions in Tanzania. The challenges of accessing microfinance services are much higher for women and the disabled, including individuals living in rural areas (Dahir, 2006; Chijoriga et al., 2009). The National Microfinance Policy (NMP) of 2017 in Tanzania aims to ensure greater access to financial services to lift people out of poverty. Hamada (2010) observes for microfinance institutions (MFIs) to extend financial and non-financial services to most clients. They have to maintain their capital by ensuring effective procedures for screening clients interested in using financial products. Also, Rooyen et al. (2012) suggest that microfinance entities' sustainability lied in setting strong principles that ensure services are extended sustainably. This can be achieved if the lending institute designs financial products needed and accessible by low-income clients. Institutions that are not sensitive to their customers' demands, coupled with weak appraisal techniques, are likely to experience loan portfolio underperformance.

Financial sustainability of microfinance institutions is necessary to ensure credit services are timely extended to needy clients for investment into productive sectors of their economy (Schreiner et al., 2000; Nyamsogoro, 2010). However, studies conducted by Gatimu \& Frederick (2014), Dahir (2006), Kar \& Swain (2014) reveal microfinance institutions are challenged by financial unsustainability in their operations. Consequently, they are unable to cope with the demand for loans from their clients. On the other hand, some lending institutes are faced with inappropriate strategies of appraising clients' loan applications to guarantee timely repayments. Any mismanagement of microfinance loan portfolios may jeopardize the firm's capital and low outreach services (Javid \& Abrar, 2015). The loan portfolio constitutes the highest proportion of revenue generation to microfinance entities. Thus, the lending institutes are required to be vigilant to ensure problem loans existing in their institutions are controlled, for enhanced credit services delivery and efficient reimbursements from clients (Hartarska \& Nadolnya, 2007).

Existing empirical studies on the determinants of useful loan appraisal to microfinance portfolio performance have reported contradictory results. Few of the determining factors are considered imperative while others not, and some contributing factors have been substantial to only a set of MFls. Studies indicating mixed conclusions on loan appraisal protocol and portfolio performance include those of Al-Azzam et al. (2012), Angaine \& Waari (2014), Shu-Teng et al. (2015), Feroze et al. (2011), D'Espallier et al. (2011), and Reta (2011). Variables such as business income, capital of borrower, borrower membership duration, and social collateral are reported to influence portfolio microfinance performance. However, evidence by Tundui \& Tundui (2013), Clamara et al. (2014), Kacem \& Zouari (2013), Mwangi \& Kihiu (2012), 
Janda \& Turbat (2013), Pasha \& Negese (2014) reported irreconcilable observation on the same.

Although there have been remarkable contributions by previous research works, many of such studies present mixed findings. In addition, some past research dealt with member-based microfinance entities (or Microfinance co-operatives), while other research was based on specific microfinance initiatives. Likely, the factors for effective loan appraisal protocol on portfolio at risk are yet to be fully recognized. Because of this, a detailed study is undertaken to focus on non-member-based microfinance entities, aiming at determining the effects of loan appraisal protocol on portfolio at risk of microfinance operation in Tanzania.

\section{Literature Review}

Credit application appraisal is at the heart of a high-quality loan portfolio of microfinance institutions (Sharma \& Kalra, 2015). The appraisal process involves determining the creditworthiness of microfinance borrowers. It intends to reduce the extent of the effect of delinquency of borrowers to the lending company. Credit application appraisal is often led by microfinance institutions' set policies on credit delivery and recovery procedures. Its purpose is to determine whether to accept microfinance borrower proposal of request for funds or otherwise. Mokhtar (2011) and Vi Ngo at el. (2014), argues that microfinance borrowers usually require funds for two types of projects for starting new businesses and for investing in continuing businesses. Thus, lending institutes need to thoroughly be informed on the consequence of both alternatives to ensure funds applied are timely repaid. In order to do so, institutions need to be informed of the factors likely to influence organizational financial performance.

According to the literature on relationship lending, borrower business income is considered to influence microfinance institutions' portfolio performance. Sharma \& Kalra (2015), Baiyegunhi et al. (2010) explain that prospective lender needs to be informed on how microfinance explainer intends to repay loans extended for continuous delivery. Lenborrowersuld is intense into consideration the cash flow from borrowers' business projects. Similarly, the repayment schedule has to inform the probability of completing their obligation on successful loan repayment. Ahmed \& Malik (2015) point out that a microfinance institution has to evaluate the borrower's business income to determine his capability to ensure regular repayments. Van Deventer et al. (2013) explain that an investment credit to a borrower that yields sufficient profit encourages them to manage timely repayment and is likely to consider for next loans. Most loan beneficiaries are capable of financing the borrowed amount without coercion. However, it is known to most lenders that some microfinance borrowers are reluctant to undertake their responsibilities of servicing the credited 
amount purposely. Hence, microfinance institutions must ensure that borrowers are screened, and their primary income sources are estimated in advance for effective repayment of the credit offered. H1. 1: Business income of microfinance borrowers has no effect on the portfolio at risk of microfinance institutions.

The collateral requirement by microfinance institutions has been considered necessary to enhance sustainable credit facilities to borrowers. Most microfinance institutions require collateral from their loan applicants before providing funds to guarantee repayment and institutional performance. Godquin (2004) adds that collateral obligation in the process of borrowing from microfinance institutions ranges up to and at times above 100 percent of the loan principal. Collateral requirements for borrowers' lending purposes are considered either as physical (traditional) collateral or social (group) collateral and personal guarantee. Lenders use these instruments as part of procedures to determine the client's worthiness before loan endorsement. However, Inkumbi (2009); Armendariz \& Morduch (2010); Babu \& Singh (2007) argues borrower's security needs to be featured by appropriate title, value stability as well as marketability. Moreover, security has to be regarded as an assurance against any unexpected event on the part of the lender. Therefore, microfinance institutions should not overlook appraising for the borrower's character and/or capacity to substitute security. Lagat et al. (2013) comment that in the process of appraising clients for a loan, consideration of safety by microfinance institutions should be the last in its options. In order to ensure repayment, microfinance entities are advised not to extend loans to clients as a substitute for the guarantee offered. Instead, the security of a borrower should only provide support in the situation a borrower defaults repayment. Similarly, Ayogyam et al. (2013) contend that to minimize problem loans, lending institutes need to conciliate various collateral forms in combination with each other to ensure loan recovery. H1. 2: Collateral requirement of microfinance borrower has no effect on portfolio at risk of microfinance institutions.

Kariuki (2010) observes that microfinance institutions need to assess borrowers' capital invested in the business for effective loan repayment. The assessment has to engage clients' financial commitment in running the business, including measures to retain the capital invested. According to Wester (1993), the capital of a borrower invested in a business reflects the business operations' financial strength in general. In addition, an emphasis has to be put on the real financial value of a client's business concern. Churchill \& Frankiewicz (2006) report most microfinance institutions face challenges in determining their applicants' overall capital (monetary terms). It has been difficult to establish what has to be the capacity of the borrower to enable effective repayment of the borrowed amount. Loan officers must do more probing to have an average amount of money as total assets to determine loan size. Unavailability and/or poor records management on the part of loan applicants is considered to contribute to delays in the process of appraising clients, including 
decisions regarding necessary repayment terms related to the loan (Nawai \& Shariff, 2013). Studies by Aliija \& Muhangi (2015) reveal that the borrower's capability to manage credit repayment highly poses a significant contribution towards a healthier loan portfolio of the lending institutes. Thus, microfinance institutions need to consider clients' capital and general business performance before extending credits to their applicants. H1. 3: Capital of microfinance borrower has no effect on portfolio at risk of microfinance institutions.

According to Hietalahti \& Linden (2006), a borrower's membership duration has a significant influence on a microfinance institution's financial performance. It is argued that borrowers frequently in contact with microfinance institutions for credit services have developed trust with the lenders and built strong attachment, including a feeling sense of ownership. It is likely to enhance effective loan repayment and diminish the risk of a microfinance loan portfolio. Maata (2004) contends that microfinance clients' creditworthiness greatly influences regular credit repayments. Addo \& Twum (2013) further add that despite the security being offered by the borrower, loan application processing and disbursement should not proceed unless borrowers' past performances are confirmed acceptable. Selection of the right type of borrower is necessary for ensuring timely loan repayment. It is the responsibility of the lending institutes to set procedures that would ensure only borrowers with acceptable previous lending institutes' responsibilities. Peprah (2012) reports that borrowers frequently accessing credit to respective microfinance institutions experienced a high loan repayment rate. Surprisingly, borrowers who rarely show up for credits raised repayment problems and risk on sustainable microlending business. Therefore, lending institutes are required to undertake thorough scrutiny on behavioral characteristics of microfinance clients interested in credits prior to credit endorsement to ensure efficient and constant repayments. H1. 4: Membership duration of microfinance borrower has no effect on portfolio at risk of microfinance institutions.

\section{Research Methods}

This paper utilizes data collected through a cross-sectional research design. The selection of a sample for the study is sourced from non-member-based microfinance entities (i.e., registration of clients is not a requirement for them to access credits) of three regions Dar es salaam, Morogoro \& Dodoma in Tanzania. Hair et al. (2006) and Tabachnik \& Fidell (2013) guided the sample size determination of this study for effective representation and analysis procedures. A semi-structured questionnaire was distributed to identified unity of analysis operating in the district of Kinondoni, Ilala, and Temeke in Dar es Salaam; Morogoro Urban district in Morogoro region, and Dodoma Urban district in Dodoma region. Returned data collection instruments underwent thorough screening prior to detailed analysis and presentation of the 
Ngonyani, D. B. (2020). “Loan Appraisal Protocol for Effective Microfinance Portfolio in Tanzania”, International Journal of Public Finance, 5(2), 193-210.

results. In this process, missing data, data validity, and outliers were checked accurately. This aimed at avoiding errors in the interpretation of the findings of the study. After screening for outliers and leverage variables, the study remained with 219 cases of targeted microfinance entities subjected to descriptive and inferential analysis.

\subsection{Research Variable Measurements}

The variables involved in this study are borrower business income, the collateral requirement of borrowers, capital of borrowers, and membership duration of borrowers. This study also employed four control variables in its analysis. Control variables aids in minimizing the risk of attributing explanatory power to an independent variable that is not, in fact, responsible for the variation observed independent variable (Milanzi, 2009). These variables are the size of MFIs, age of MFls, the manager's experience, and the manager's education level.

Table 1: Measurement of Variables

\begin{tabular}{|c|c|}
\hline Variable Name & Description and measurements \\
\hline $\begin{array}{l}\text { Borrowers business } \\
\quad \text { income }\end{array}$ & Average annual business income of MFIs borrower in TZS (continuous variable) \\
\hline $\begin{array}{l}\text { The collateral requirement } \\
\text { of borrowers }\end{array}$ & $\begin{array}{l}\text { The proportion of kinds of collateral required by MFIs. } \\
\text { (dummy, } 0=\text { physical collateral; } 1=\text { social collateral; and 2=personal guarantee) } \\
\text { (categorical variable) }\end{array}$ \\
\hline Capital of borrowers & $\begin{array}{l}\text { The average annual monetary value of MFI borrowers' assets in TZS (continuous } \\
\text { variable) }\end{array}$ \\
\hline $\begin{array}{l}\text { Membership duration of } \\
\text { borrowers }\end{array}$ & Frequency of borrowers accessing credit to MFIs in months (continuous variable) \\
\hline Control variables & Measurement procedure \\
\hline MFIs size & Total assets of a microfinance institution in TZS. \\
\hline MFls age & Number of years since the establishment \\
\hline Manager experiences & Number of years of working in the microfinance industry \\
\hline $\begin{array}{l}\text { Manager education } \\
\text { qualifications }\end{array}$ & $\begin{array}{l}\text { Education qualification attained by the MFI manager. 1=Secondary education; } \\
2 \text { 2=Technical education; } 3=\text { University education }\end{array}$ \\
\hline
\end{tabular}

Measurement of the dependent variable

The dependent variable in this study is measured by: 
Ngonyani, D. B. (2020). “Loan Appraisal Protocol for Effective Microfinance Portfolio in Tanzania”, International Journal of Public Finance, 5(2), 193-210.

Portfolio at risk (PAR) 90 days $=$

\section{Outstanding principal balance of all loans past due more than 90 days Outstanding principal balance of all loans}

In order to examine the relationship between independent and dependent variables of this study while controlling for observed attributes. The study uses ordinary least square regression for determining unknown parameters in the model. The following linear regression model is applied:

$$
P A R=\beta_{0}+\beta_{1} B \mathrm{BI}_{t}+\beta_{3} \mathrm{SOCOR}_{t}+\beta_{4} \mathrm{PERG}_{t}+\beta_{5} \mathrm{CAB}_{t}+\beta_{6} \mathrm{MED}_{t}+\sum \theta_{i} \psi_{i t}+\varepsilon_{t}
$$

In the above model, PAR is the outcome variable, BBI indicates borrower business income, SOCOR is social collateral, PERG is a personal guarantee, CAB is capital of borrowers, MED is the membership duration of a borrower. The $\psi$ presents control variables, including the size of MFIs, age of MFls, the manager's experience, and the manager's education level.

\subsection{Descriptive Statistics}

The descriptive results of the study are presented in Table 2 below. The presentation of this information acts as a foothold toward comprehensive model analyses on the study objective. Table 2 below presents data of surveyed microfinance institutions on the mean value for average capital of borrowers for the study period to be TZS 7,179,086.77 (equal to USD $3101.5^{2}$ ). This amount ranges between TZS $500,000.00$ (equal to USD 216) as a minimum and TZS 15,000,000.00 (equal to USD 6480.3) maximum. The variation in recorded information during the period is TZS $3,682,950.67$ (equal to USD 1591.1). This indicates microfinance clients in study areas had relatively low capital for their businesses. These results inform further that microfinance institutions need to be conscious when extending credit facilities to their clients to avoid repayment problems.

On the other hand, Table 2 exhibits a record of borrowers' frequency in accessing credits from microfinance institutions with an average value of 28.89 months. This study recorded a minimum and maximum of 6 and 58 months of contacts, respectively, with the lending institutes. This implies that lending institutes are required to employ effective appraisal procedures to ensure credits are extended to deserving clients capable of discharging their loan obligations.

\footnotetext{
${ }^{2}$ Exchange rate applied is 1 USD $=$ TZS 2,314.72 as of $09^{\text {th }}$ April 2020
} 
Ngonyani, D. B. (2020). “Loan Appraisal Protocol for Effective Microfinance Portfolio in Tanzania”, International Journal of Public Finance, 5(2), 193-210.

The variable borrower business income depicts a minimum and maximum of TZS 1,500,000.00 (equivalent to USD 648) and TZS 20,000,000.00 (equal to USD 8640.4) respectively. Moreover, surveyed MFIs showed a mean value of borrower business income of TZS 8,201,415.53 (equal to USD 3543.2) during the period of study. This indicates microfinance borrowers experience low returns in their business. Consequently, they are likely to fail in servicing the borrowed funds effectively to guarantee a healthy loan portfolio of the lending institutions.

Table 2: Descriptive Results

\begin{tabular}{lccccc}
\hline \multicolumn{1}{c}{ Variable } & Mean & Std. Dev & Min & Max & N \\
\hline Capital of borrower (TZS) & $7,179,086.77$ & $3,682,950.67$ & 500,000 & $15,000,000$ & 219 \\
Borrower frequency to MFI & 28.89 & 12.018 & 6 & 58 & 219 \\
& & & & & \\
Borrower business income (TZS) & $8,201,415.53$ & $5,974,260$ & $1,500,000$ & $20,000,000$ & 219 \\
\hline
\end{tabular}

\subsubsection{Descriptive Results on Collateral Requirement of Borrowers}

The surveyed microfinance institutions present collateral requirements for borrowers to access loan services offered. The study indicates that $48.9 \%$ (107) of microfinance institutions preferred borrowers to have physical kind of collateral to enable access credits. On the other hand, $44.3 \%$ (97) of microfinance institutions required loan applicants to use social collateral (group lending approach) in launching loan requests to MFIs. Furthermore, 6.8\% (15) of microfinance institutions accepted personal collateral (personal guarantee) in processing and granting credits to loan applicants. This distribution suggests the majority of microfinance institutions in the study areas preferred borrowers to use the physical collateral approach (traditional collateral), followed by group lending when intending to access microcredit services. This further means that microfinance institutions in studied areas consider these two lending approaches relevant, resulting in high repayment rates and reduced portfolio risk.

Table 3: Descriptive Results on Collateral Requirement of Borrowers

\begin{tabular}{lcc}
\hline & \multicolumn{2}{c}{ Microfinance institutions } \\
\hline & Number & $\%$ \\
\cline { 2 - 3 } Physical collateral & 107 & 48.9 \\
Social collateral & 97 & 44.3 \\
Personal collateral & 15 & 6.8 \\
Total & 219 & 100.0 \\
\hline
\end{tabular}




\subsubsection{Assumptions Associated with Model of Analysis}

The ordinary least square (OLS) regression model is used in determining the effects of credit application protocol on portfolio at risk of non-member-based microfinance entities. To enhance the validity and reliability of findings, the study tested for model assumptions to ensure that no violations before actual data analysis are made.

The normality of the dependent and some independent continuous variables are checked by the Shapiro-Wilk test, Kolmogorov-Smirnov, and visual scatterplots. The observation through the scatterplot matrix reveals data are almost normally distributed. In addition, the output of the test statistics revealed a p-value of 0.067 for Shapiro - Wilk test and a p-value of 0.201 for the Kolmogorov-Smirnov test. These values are above the $p$-value 0.05 . Therefore, it is evident that the data are approximately normally distributed (Keenan \& Stevens, 2016).

Similarly, an independent test of observation was conducted to confirm the data are in line with a linear regression model's requirement. Durbin Waston test statistics are used for that purpose. The statistic test showed 2.026 indices; thus, this assumption is not violated. The linearity of the data set was achieved through visual inspection of the relationship of the scatterplot matrix. Since normality was attained, that also guaranteed the existence of linearity of the data set in this study. Homoscedasticity is equally tested and observed, not violated since the dependent variable's variance is explained in the dependence relationship. It was not concentrated in only a limited range of the independent values observed in the scatter plot.

Finally, the multicollinearity assumption is checked using a correlation matrix and variation inflation factor (VIF). This study confirmed VIF not exceeding 2.0 among regressed variables; therefore, it shows a multicollinearity problem is not an issue of concern. In addition, the correlation matrix is also shown below, assisting as a check for collinearity between variables employed in the OLS regression model. Therefore, it is noted that the correlation analysis portrays the absence of collinearity problems between variables under study (Hair et al., 2010). 
Ngonyani, D. B. (2020). “Loan Appraisal Protocol for Effective Microfinance Portfolio in Tanzania”, International Journal of Public Finance, 5(2), 193-210.

Table 4: Correlations Matrix among the Study Variables

\begin{tabular}{lrrrrrrrrr}
\hline VARIABLES & PAR & MED & CAB & BBI & SOCOR & PERG & MANEX & MFISIZE & MANEDU \\
\hline PAR & 1 & & & & & & & \\
MED & $-.166^{*}$ & 1 & & & & & & \\
CAB & $-.211^{* *}$ & -0.014 & 1 & & & & & \\
BBI & $-.244^{* *}$ & 0.064 & $.393^{* *}$ & 1 & & & & \\
SOCOR & $-.175^{* *}$ & -0.013 & -0.009 & 0.089 & 1 & & & \\
PERG & 0.009 & -0.028 & 0.005 & $.136^{*}$ & $-.231^{* *}$ & 1 & & \\
MANEX & 0.088 & -0.063 & $.134^{*}$ & 0.094 & -0.017 & 0.066 & 1 & & \\
MFIAGE & -0.063 & -0.071 & 0.027 & 0.053 & 0.029 & 0.056 & 0.026 & 1 & \\
MFISIZE & $.157^{*}$ & -0.061 & -0.024 & -0.007 & $-.179^{* *}$ & 0.078 & 0.048 & $-.133^{*}$ & \\
MANEDU & 0.021 & 0.071 & 0.007 & -0.006 & 0.059 & -0.1 & -0.09 & 0.13 & $-.246^{* *}$ \\
\hline
\end{tabular}

${ }^{*}$. Correlation is significant at the 0.05 level (2-tailed).

${ }^{* *}$. Correlation is significant at the 0.01 level (2-tailed).

\subsubsection{Regression Analysis Results}

The study uses the ordinary least square (OLS) model to test the influence of credit application protocol on the portfolio at risk of the microfinance institution. Before testing the hypothesis related to each variable of a credit application appraisal, an overall model fit was used to test the combined effects of all variables on the portfolio at risk of microfinance entities. The comprehensive model is significant at $F(10,208)=18.906 ; p=.000<.05$, which also pointed in general, the concepts selected for this study did indeed explain a significant proportion of the variance in the portfolio at risk of microfinance companies. The estimated results of the OLS model of analysis are quite at a satisfactory level. Adjusted $R^{2}$ is 0.449 , and the observed $R^{2}$ value is 0.476 , respectively. This means that independent variables can explain $47.6 \%$ of the portfolio at risk of the microfinance institution.

R-Square 0.476, Adjusted R-Square 0.449, F-Statistic 18.906, Prob. (F-stat) .000, Number of observations 219, Significance at 5\%, PAR is outcome variable presents for the portfolio at risk; $B B I$ is borrower business income; $C A B$ is capital of borrowers; MED is membership duration of the borrower; SOCOR is social collateral; PERG is a personal guarantee; MFISIZE is the size of microfinance institutions; MFIAGE is the age of microfinance institutions; MANEX is an experience of the manager, and MANEDU is education level of manager. 
Ngonyani, D. B. (2020). “Loan Appraisal Protocol for Effective Microfinance Portfolio in Tanzania”, International Journal of Public Finance, 5(2), 193-210.

Table 5: Model Results for Loan Appraisal Protocol Variables on PAR of MFIs

\begin{tabular}{lllll}
\hline \multicolumn{1}{c}{ Variables } & Coefficients & Standard & T Value & P Value \\
\hline & & Error & & \\
\hline (Constant) & 19.553 & 8.337 & 2.345 & 0.02 \\
CAB & -1.534 & 0.662 & -2.316 & 0.022 \\
MED & -0.039 & 0.016 & -2.4 & 0.017 \\
BBI & -1.478 & 0.646 & -2.287 & 0.023 \\
SOCOR & -0.884 & 0.408 & -2.167 & 0.031 \\
PERG & -0.156 & 0.791 & -0.197 & 0.844 \\
MANEX & 0.106 & 0.059 & 1.799 & 0.074 \\
MFIAGE & -0.072 & 0.089 & -0.813 & 0.417 \\
MFISIZE & 1.271 & 0.772 & 1.648 & 0.101 \\
MANEDU & 0.631 & 0.619 & 1.02 & 0.309 \\
\hline
\end{tabular}

\section{Results and Discussion}

The findings in Table 5 show variable capital of borrowers (CAB) depicts negatively and statistically significant at $5 \%$ with a regression coefficient of -1.534 . It suggests keeping all other factors constant, an increase of microfinance entities that extends credits to borrowers with sufficient capital in the business, results in a 1.5 unit decrease in risk of the loan portfolio of respective lending institutes. Therefore, microfinance entities providing credit facilities to borrowers with relatively high capital in their business are likely to be effective in their business investment options, thus negatively associated with repayment problems. Microfinance borrowers' high capital indicates commitment and experience of borrowers in managing their business, leading to effective loan repayment, hence low portfolio at risk. This finding is in line with Hunte (1996), Bayeh (2012), Sharma \& Kalra (2015), who point out that MFIs should take long assessing loan applicants to minimize delinquency and achieve an acceptable portfolio at risk of the company. Therefore, MFIs that thoroughly appraise loan applicants are likely to have righteous borrowers resulting in the reduced portfolio at risk and sustainable financial performance.

Similarly, the variable membership duration of the borrower (MED) reads negatively related and significant at the level of $5 \%(p=0.017)$. The findings, therefore, 
imply that a unit increase of microfinance loans to borrowers who are frequently willing to access credit facilities will reduce the risk of the microfinance loan portfolio by almost 0.034 units. Put it differently, microfinance entities that retain their borrowers through loan services make them undertake their obligation of repayments resulting in the low portfolio at risk. In addition, it makes clients own the services offered by the company and ensure healthy financial performance for sustainable service provision. Kuhn \& Darroch (1999), as well as Vi Ngo et al. (2014), documented similar observations in their studies that microfinance clients frequently served with loans build confidence, react positively on repayments to enable a healthy loan portfolio.

Moreover, the variable borrower business income (BBI) indicates in regression results output negatively related and statistically significant at $5 \%(p=0.023)$ with a coefficient of -1.478 .

This implies that a unit increase of microfinance loans to borrowers with high business income results in a 1.478 unit decrease of the portfolio at risk of the microfinance institution. Hence, to ensure a healthy loan portfolio, the lending institutes need to consider the sound cash flow of microfinance clients' primary business. This finding is parallel with Quayes (2012), Ahmed \& Malik (2015), Baiyegunhi et al. (2010) who portray that MFls effective evaluation of borrowers' business incomes contributes to high loan recovery and reduced risks of microfinance performance.

Furthermore, the category social collateral of microfinance borrower in table 5 is negatively and statistically significant at $5 \%$. Its coefficient -0.884 , indicating that, influences the PAR of microfinance companies. The findings imply that microfinance institutions can minimize problems associated with the underperformance of credit services, including reducing loans portfolio at risk, when the emphasis is put toward loan applicants using social capital as a condition for accessing credits to lending institutes. Studies by Armendariz \& Morduch (2000); Lilay et al. (2015) records that group lending improves loan repayment, decreases the risk of borrower defaults, and enhances the lending's financial performance institutes.

\section{Conclusion}

This study establishes the impact of loan appraisal protocol for an effective microfinance portfolio in Tanzania. It records that borrower business income, capital of borrower, membership duration of the borrower, and the borrower's social collateral determines portfolio at risk of microfinance entities. The study has revealed that all identified factors negatively and significantly impact the loan portfolio of microfinance performance. Empirical findings of this study, therefore, suggest that microfinance 
entities can benefit from four empirically tested relationship to enhance reduction of risk of microfinance loan portfolios: (a) microfinance institutions need to consider sound cash flow of the main business of microfinance client before extending credit; (b) lending institutes should undertake effective appraisal to borrowers to ensure those with relatively high capital in their business are offered loans facilities; (c) Similarly, they should extend credits to microfinance clients that frequently willing to access credit facilities to enhance regular repayments; (d) microfinance institutions should put emphasis on social capital as a condition for accessing credits to lending institutes. Microfinance borrowers with observed characteristics are proven to have a low delinquency rate to enabled microfinance institutions to experience high loan recovery and low portfolio at risk for sustainable financial performance. 


\section{References}

Addo C. K. \& Twum S.B. (2013). "Sustainability of Microfinance in Developing Countries through Credit Risk Management: Evidence from Business Experience, Purpose of Loan, Long Term, Profit Maximization Motive", Global Journal Finance and Banking, (7), 9-18.

Ahmed, S \& Malik, A. Q. (2015). “Credit Risk Management and Loan Performance: Empirical Investigation of Micro Finance Banks of Pakistan", International Journal of Economics and Financial 5(2),574-579.

Al-Azzam, M., Mimouni, K \& Ali, M.A, (2012). "The Impact of Socioeconomic Factors and Financial Access on Microfinance Institutions", International Journal of Economics and Finance, 4(4), 61-71.

Aliija, R \& Muhangi, W.B. (2015). "The Effect of Loan Appraisal Process Management on Credit Performance in Microfinance Institutions (MFIs): A Case of MFIs in Uganda", International Journal of Science and Research (IJSR), 4(1), 150-168.

Angaine, F \& Waari, D.N. (2014). "Factors Influencing Loan Repayment in MicroFinance Institutions in Kenya", Journal of Business and Management, 16(9), 66-72.

Armendáriz, B. \& Morduch, J. (2010). The Economics of Microfinance, The MIT Press Cambridge, Massachusetts London, England.

Armendariz B. \& Morduch, J. (2000). "Microfinance Beyond Group Lending", Economics of Transition, 8, 401-420.

Arthur, J., Apanga, M. \& Appiah, K.O. (2016). “Credit Risk Management of Ghanian Listed Banks", International Journal of Law and Management, 58(2), 162-178.

Ayogyam, A., Goddana, M.D., Mohammed, H. \& Boateng, E. (2013). “Monitoring Loan Repayment among Farmers in Techiman, Ghana: Investigating the Effect of Cooperative Farming System", Journal of Emerging Trends in Economics and Management Sciences (JETEMS), 5(1), 32-37.

Babu, S. \& Singh, A. (2007). "The Need for Individual Lending in Mature Microfinance Institutions", Eye on Microfinance, 4, 1-7.

Baiyegunhi, L.J.; Fraser, G.C.G \& Darroch, M. A, (2010). "Credit Constraints and Household Welfare in the Eastern Cape Province, South Africa", African Journal of Agricultural Research, 5(16), 2243-2252.

Bayeh A. K. (2012). "Financial Sustainability of Microfinance Institutions (MFIs) in Ethiopia", European Journal of Business and Management, 4(15), 1-9.

Chijoriga, M. M., Mori, N. \& Olomi, D.R. (2009). Microfinance: In Africa Entrepreneurship and Small Business Development, Context and Process, Oteman Ltd, Dar es Salaam, Tanzania. 
Churchill, C. \& Frankiewicz, C. (2006). Making Microfinance Work: Managing for Improved Performance, The International Training Centre of the ILO in Turin, Italy.

Clamara, N., Pena, X., \& Tuesta, D. (2014). Factors that Matter for Financial Inclusion: Evidence from Peru, Working Paper No. 14/09, BBVA Research, Madrid.

Dahir, M. A. M (2006). "The Challenges Facing Microfinance Institutions in Poverty Eradication: A Case Study in Mogadishu", International Journal of Humanities Social Sciences and Education (IJHSSE), 2(2), 56-62.

D'Espallier, B., Guerin, I. \& Mersland, R. (2011). "Women and Repayment in Microfinance: A Global Analysis", World Development, 39(5), 758-772.

Feroze, S.M, Chauhan, A.K., Malhotra, R. \& Kadian, K.S, (2011). “Factors Influencing Group Repayment Performance in Haryana: Application of Tobit Model", Agricultural Economics Research Review, 24, 57-65.

Gatimu, E.M., \& Frederick, M.K. (2014). “Assessing Institutional Factors Contributing to Loan Defaulting in Microfinance Institutions in Kenya", Journal of Humanities and Social Science, 19, 105-123.

Godquin, M. (2004). "Microfinance Repayment Performance in Bangladesh: How to Improve the Allocation of Loans by MFIs", World Development, 32(11), 1909-1926.

Hamada, M. (2010). "Financial Services to the Poor: An Introduction to the Special Issue on Microfinance", The Developing Economies, 38(1), 1-14.

Hair, J.F.; Black, W.C.; Babin, B.J.; Anderson, R.E. \& Tatham, R.L. (2006). Multivariate Data Analysis, 6th Edition, Pearson Education Inc. USA.

Hair, J.F., Black. W.C., Babib. B.J., \& Anderson, R.E. (2010). Multivariate Data Analysis, 7th edition, Pearson Prentice Hall, New York.

Hartarska, V. \& Nadolnya, D. (2007). "Do Regulated Microfinance Institutions Achieve better Sustainability and Outreach? Cross-country Evidence", Applied Economics, 39, 1207-1222.

Hietalahti, J., \& Linden, M. (2006). "Socio-Economic Impacts of Microfinance and Repayment Performance: A Case Study of the Small Enterprise Foundation, South Africa", Progress in Development Studies, 6(3), 201-210.

Hunte, J (1996). Microfinance and Poverty Alleviation: Case Studies from Asia and the Pacific. Routledge; USA Kuhn M.E \& Darroch.

Inkumbi, M. (2009). "Beyond the 5Cs of Lending", Accounting, Auditing and Accountability Journal, 16(4), 640-661. 
Ishengoma, E. K. (2010) "Financial Linkages and Cost Efficiency: Lessons from Microfinance Cooperatives in Tanzania", Business Management Review, 14, $1-29$.

Janda, K. \& Turbat, B. (2013). Factors Influencing Portfolio Yield of Microfinance Institutions in Central Asia, Munich Personal RePEc Archive, Paper No. 49549, http://mpra.ub.uni-muenchen.de/49549/.

Javid, A.Y. \& Abrar, A. (2015). “Microfinance Institutions and Poverty Reduction: A Cross Regional Analysis", The Pakistan Development Review, 54(4), 371-387.

Kacem, S. B \& Zouari, S. G (2013). "The Determinants of Access of Financial Services for Sicrocredit Association: Application on Tunisian Case", Journal of Business Management and Economics, 4(2), 031-046.

Kar, A.K., \& Swain, R.B. (2014). Competition, performance and portfolio quality in microfinance markets, Working Paper Series 2014:8, Department of Economics, Uppsala University.

Kariuki, J. N. (2010). Effective Collection Policy, Nairobi; KASNEB Publishers.

Keenan, A, \& Stevens, P. J. (2016). Applied Multivariate Statistics for Social Sciences, Analysis with SAS and IBM'S SPSS, 6th Edition, Routledge Taylor \& Francis Group, New York.

Kessy, S.A. \& Urio, F.M. (2006). The Contribution of Microfinance Institutions to Poverty Reduction in Tanzania, REPOA Research Report, Mkuki na Nyota Publishers.

Dar es Salaam Tanzania.

Kuhn M.E \& Darroch. M. (1999). Factors Affecting Rural Medium-term Loan Repayment: Evidence from a South African Development Finance Institution, International Association of Agricultural Economists (IAAE), Ashgate Publishing Co. Ltd, UK.

Lagat, F.K., Mugo, R. \& Otuya, R. (2013). “Effect of Credit Risk Management Practices on Lending Portfolio Among Savings and Credit Cooperatives in Kenya", International Journal of Science Commerce and Humanities, 1(5), 93-106.

Lilay, W.L., Desta, T. \& Wondmagehn. (2015) “Factors Influencing MFIs Group Loan Repayment Performance: A Case of MSEs Service Sector in Mekelle City, Ethiopia", Research Journal of Finance and Accounting, 6(5), 154-170.

Maata, D. (2004). "Examining Determinants of Group Loan Repayment in the Dominican Republic", Master Thesis, The Ohio State University. United States of America.

Mapesa, H. J. (2012). "Impact of Access to Microfinance Services on Farm Households' Income in Iringa Region, Tanzania", PhD Thesis, Sokoine University of Agriculture Morogoro, Tanzania. 
Mwangi, I.W \& Kihiu, E.N (2012). "Impact of Financial Literacy on Access to Financial Services in Kenya", Internal Journal of Business and Social Science, 3(19), 212-222.

Nawai, N \& Shariff, M. M. (2013). "Loan Repayment Problems in Microfinance Programme that use Individual Lending Approach: A Qualitative Analysis", International Journal, 1(1), 88-97.

Nyamsogoro, G.D (2010). "Financial Sustainability of Rural Microfinance Institutions in Tanzania", PhD. Thesis, University of Greenwich, United Kingdom.

Pasha, S.A.M. \& Negese, T. (2014). "Performance of Loan Repayment Determinants in Ethiopian Micro Finance-An Analysis", Eurasian Journal of Business and Economics, 7(13), 29-49.

Peprah, J. A (2012). "Access to Microcredit Well-being among Women Entrepreneurs in the Mfantsiman Municipality of Ghana", International Journal of Finance \& Banking Studies, 1(1), 34-36.

Quayes, S. (2012). "Depth of Outreach and Financial Sustainability of Microfinance Institutions", Applied Economics, 44, 3421-3433.

Reta, F. K. (2011). "Determinants of Loan Repayment Performance: A Case Study on Addis Credit and Saving Institution, Addis Ababa", Master Thesis, Wageningen University.

Rooyen, C. V., Stewart, R. \& Wet, T.D. (2012). "The Impact of Microfinance in SubSaharan Africa: A Systematic Review of the Evidence", World Development, 40(11), 2249-2262.

Sharma, S \& Kalra, P. (2015). "An Overview of Credit Appraisal System with Special Reference to Micro, Small and Medium Enterprises (MSME)", Pacific Business Review International, 7(11), 94-104.

Shu-Teng, L., Zariyawati, M.A., Suraya-Hanim, M., \& Annuar, M.N (2015). "Determinants of Microfinance Repayment Performance: Evidence from Small Medium Enterprises in Malaysia", International Journal of Economics and Finance, 7(11), 110-120.

Schreiner, M. Navajas. S. Meyer, R.L.; Gonzalenzvega, C.; \& Rodriguezmeza, J. (2000). "Microcredit and the Poorest of the Poor: Theory and Evidence from Bolivia", World Development, 28(3), 333-346.

Tabachnik, B.G. \& Fidell, L.S. (2013). Using Multivariate Statistics, 6th edition, Pearson Education, Inc. U.S.A.

Tundui, C. \& Tundui, H. (2013). "Microcredit, Micro Enterprising and Repayment Myth: The Case of Micro and Small Women Business Entrepreneurs in Tanzania", American Journal of Business and Management, 2(1), 20-30. 
Ngonyani, D. B. (2020). “Loan Appraisal Protocol for Effective Microfinance Portfolio in Tanzania”, International Journal of Public Finance, 5(2), 193-210.

Van Deventer, D. R.; Imai, K. \& Mesler, M (2013). Advanced Financial Risk Management Tools and Techniques for Integrated Credit Risk and Interest Rate Risk Management, Second Edition, John. Wiley \& Sons Singapore Pte. Ltd.

Vi Ngo, T., Mullineux, A.W. \& Anh Hoang Ly. A (2014). "The impact of scale of operation on financial performance in microfinance", Eurasian Economic Review, 4, 177-198.

Wester, G. (1993). "Essays on Regulation and Supervision", International Small Business Journal, 11, 35-46. 